\title{
Structural Integration: Origins and Development
}

\author{
Eric Jacobson, $\mathrm{PhD}$
}

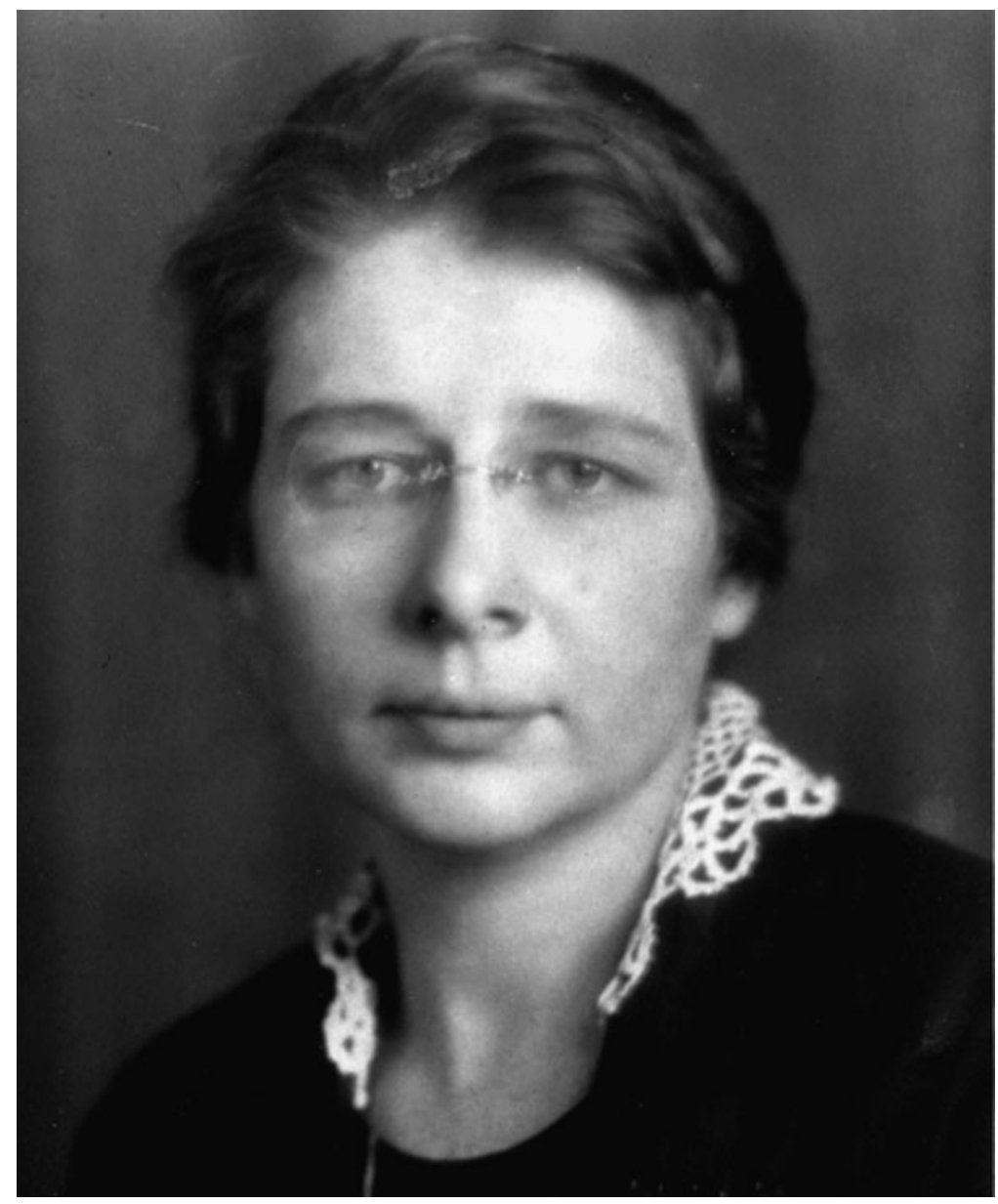

Ida Pauline Rolf, PhD (1896-1979) in 1924. Photograph courtesy of Rockefeller Archive Center.

\section{Introduction}

$S^{\text {nte }}$ TRUCtural Integration (SI) is a system of manual therapy and sensorimotor education that purports to improve human biomechanical functioning as a whole rather than to treat particular symptoms. This article briefly reviews its origin and development; the theory, clinical methods, and scientific research have been summarized elsewhere. ${ }^{1}$ The content presented here was drawn from the existing literature, the author's training experience with the method's originator, and consultation with other senior SI practitioners.

\section{Origins and Early Development}

SI was developed and propagated by the biochemist Ida Pauline Rolf, PhD (1896-1979) outside of orthodox medical 
science. ${ }^{2}$ Prior to her invention of this approach, Rolf completed a doctorate in biochemistry at Columbia University and was the first woman to hold a research post at the Rockefeller Foundation (1917-1927), where she coauthored over a dozen research articles on the chemistry of lipids, mostly with her mentor Phoebus Levin. * Following her tenure there, Rolf studied mathematics, physics and homeopathy for 2 years in Switzerland, Germany, and France.

Although primary literature on the early development of SI is limited, ${ }^{3-10}$ it is clear that the most formative influences on Rolf's thinking were osteopathy, hatha yoga, a number of closely related postural training and movement awareness therapies, and the General Semantics of Alfred Korzybski.

Rolf took an early and active interest in osteopathic manipulation. She attended at least one class with William Sutherland, the originator of cranial osteopathy, ${ }^{11}$ and maintained a long friendship with the cranial osteopath Isabel Biddle. She also took instruction in Physiosynthesis, a system of exercise intended to improve biomechanics, with its inventor the osteopath Amy Cochran, ${ }^{12}$ and is said to have been influenced in addition by the osteopaths Kenneth Little and John Wrenham. In addition to the fundamental osteopathic notions that optimizing human biomechanics confers broad health benefits and that restoring motility to the joints would improve fluid flow through the body, thus promoting "natural healing," Rolf also absorbed the insight that the myofascial network - "the organ of form" — was a key determinant of bony alignment, posture, and movement. ${ }^{13}$

Rolf was conversant with several postural training methods that were propagated in the United States in the first half of the 20th century. ${ }^{14-16}$ Formatting her work as a series of 10 sessions, each pursuing specific biomechanical goals, may have been prompted by the movement awareness method of Lawson-Woods, who had formatted his method as a series of 10 lessons. ${ }^{17}$ The work of Jeannette Lee, a proponent of the sensorimotor education system of Matthias Alexander, was another important influence, as were the movement awareness methods of Elsa Gindler, Charlotte Selver, and Moshe Feldenkrais. $^{18-20}$

Rolf was a long-term practitioner of hatha yoga, for many years under the tutelage of the self-styled tantric yogi Pierre Bernard (Peter Coon) who, beginning in 1920, presided over an institute on the Hudson valley. ${ }^{21,22}$ This may have contributed to her emphasis on the vertical axis as the essential postural ideal (Fig. 1).$^{\dagger}$

A more intellectually abstract but equally important influence was Alfred Korzybski's theory of General Semantics, in particular the ideas that linear cause-effect models are inadequate to explain living phenomena, that "the map is not the territory" (i.e., theory is no substitute for experiential familiarity), and that the colloidal components of connective tissue may be especially suited as a medium through which the effects of local stimuli might be transmitted throughout an organism. ${ }^{23}$ Rolf attended several seminars of the Institute for General Semantics.

*These appeared in the Journal of Biological Chemistry and are available for download at www.jbc.org Accessed on April 1, 2011.

${ }^{\dagger}$ Fig. 1 is a registered service mark of the Rolf Institute of Structural Integration.

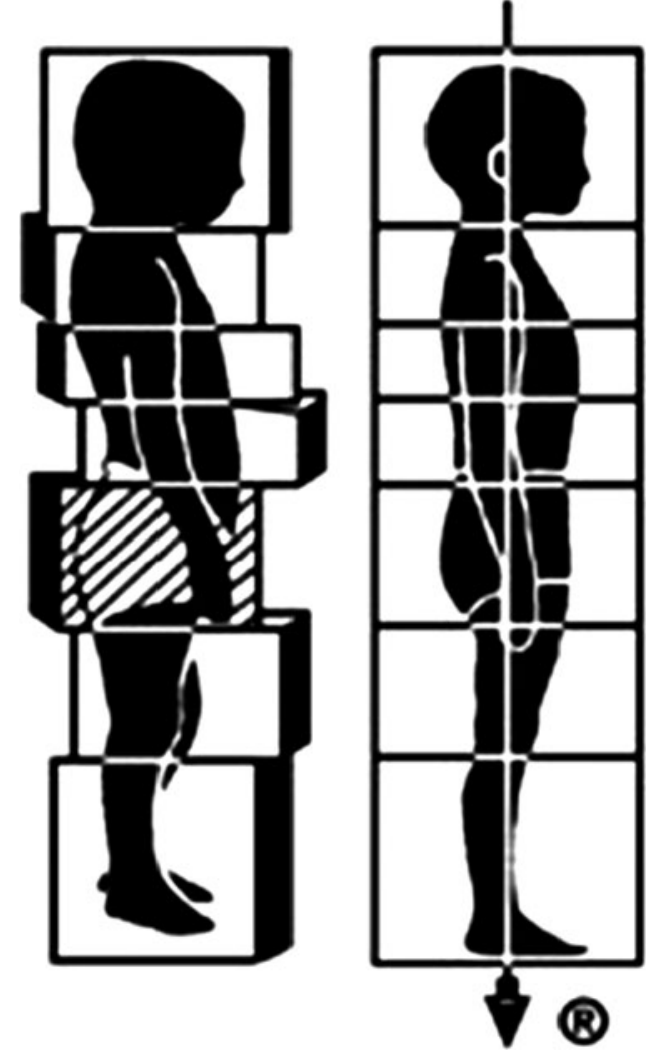

FIG. 1. Dr. Rolf's Little Man logo illustrating the "random body" and the goal of postural alignment with gravity. Courtesy of the Rolf Institute of Structural Integration. ${ }^{\circledR}$

Rolf also referred to Buckminster Fuller's concept of "tensegrity structures" in which the overall geometry is determined by the balance of tensional elements that are held apart from one another in specific spatial relationships by rigid struts as is the fabric of a tent, rather than by the stacking of compressive elements as in a traditional building. In such structures, locally induced strains alter the overall geometry of the larger structure. ${ }^{24}$

Rolf was also familiar with the somatic psychotherapy of Wilhelm Reich, who resided and taught in the northeastern United States during 1939-1957. His writings would have been a primary source for the idea that chronic patterns of muscular tension can store negative emotions, thereby perpetuating the influence of those emotions on the individual personality. Reich described the elicitation of catharses that he believed to be the release of such stored emotions, through the application of manual pressure to chronically tense muscles. He believed that this method freed up "orgone energy" that had been bound up in the tension, thus producing a "genital character" that would be free of neurosis. ${ }^{25}$ Here again Rolf encountered a system of bodily manipulation claiming to produce a level of health and wellbeing that was far above the norm.

We see in these influences the seeds of key elements of Rolf's theory and method: The osteopathic insight that the adequacy of the individual's biomechanics is of great import for their overall health and well-being, and can be improved 
by manipulation; the importance of sensorimotor education in achieving energetically efficient posture and movement; the yogic emphasis on postural alignment around a central, vertical axis; and the views of Feldekrais, Reich, and others that chronic patterns of restricted movement and posture were directly tied to chronic emotional and behavioral problems.

Rolf organized these ideas around her own conviction that the adequacy of the individual's adaptation to gravity-an ubiquitous, unrelenting force to which all human structures must adapt throughout their lifecycle-was a key determinant of physical and psychologic health. The explicit goal of her method was the integration of the individual's energy field with that of gravity. This was to be achieved by aligning their physical structure around the vertical vector that gravity defines. The individual's relationship with gravity would then be transformed from one of struggle and eventual collapse, to one in which the integrity of their physical structure - as well as their character-was "reinforced" by a balanced "flow" of gravitational energy. The individual who was "integrated with gravity" would manifest a higher level of "maturity."

Central to Rolf's clinical method was the idea that the balance or imbalance in tone of fascial structures was a potent determinant of bony alignment and joint function (i.e., that the human body was in important respects a tensegrity structure). Improving "equipoise" of fascial tone throughout the body would allow its central axis to align more closely with the gravitational vertical and even to extend upward by more fully evoking the antigravity reflex. This could be achieved by increasing the pliability of selected fascias through skilled manipulation. Rolf also taught other hallmarks of biomechanical excellence to guide clinical practice. These include bilateral symmetry, anterior-posterior "horizontality" of the major body segments (Fig. 2), and "grace" in movement, most easily observed in the extent of crossextensor activation in walking. Education and awareness exercises designed to increase the individual's ability to sense the difference between postures and movements that more versus less closely approximate these ideals were an essential supplement to the manual therapy.

\section{Early Development and Literature}

Rolf began doing manual therapy in or about 1940. During the late 1940s and 1950s, she taught her method, which she initially referred to as Structural Dynamics, in summer courses first at the European College of Osteopathy at Maidstone, England and then at an institute in Surrey devoted to the teachings of the mystic Georges Gurdjieff. Her earliest formal class in the United States was given in 1953 in Los Angeles. During this early period, Rolf also traveled extensively, demonstrating her methods to groups of osteopaths and chiropractors. Until shortly before her death in 1979, she taught widely in the United States and abroad, earning a reputation for producing dramatic improvements in posture and musculoskeletal dysfunction.

A video transfer of a 1970 film by Robert Pritchard of Dr. Rolf lecture-demonstration at Esalen Institute, Big Sur, California is available from rolf.org/risi/store Accessed April 1, 2011.
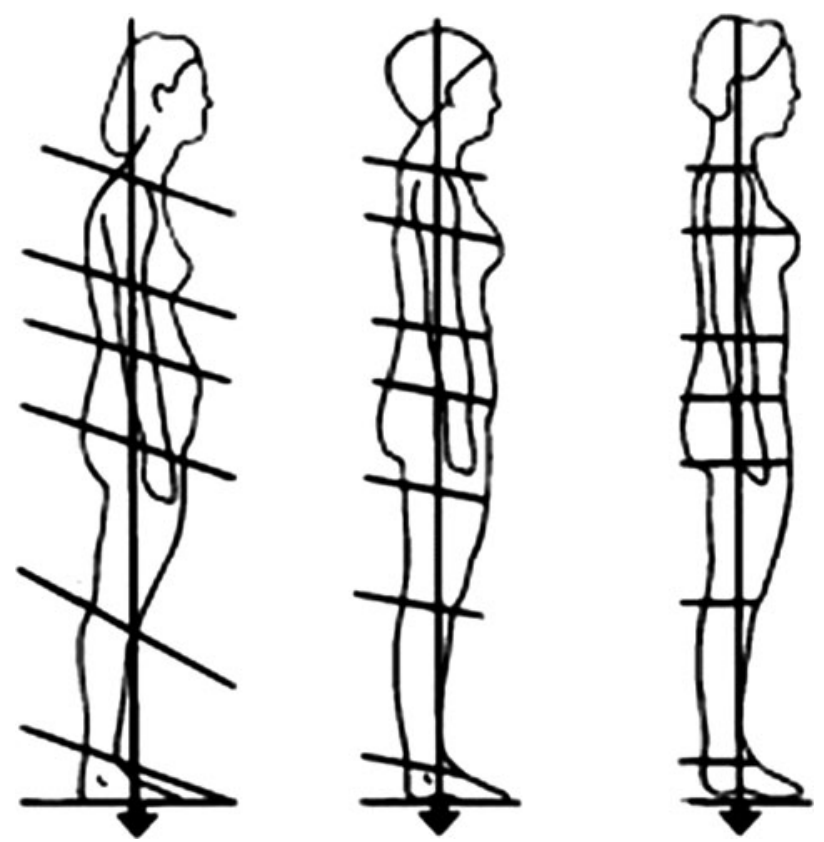

FIG. 2. Successive approximation of horizontals in the human structure; one of the criteria of biomechanical excellence taught by Dr. Rolf. From Rolf, $1977 .^{2}$ Used by permission.

The earliest published description of Rolf's 10-session method was authored in 1958 by Lawson-Woods. ${ }^{17}$ The Boston osteopath Marvin Solit produced a more comprehensive account in 1962, which included before-and-after photographs illustrating dramatic postural changes. ${ }^{26}$ Two years later the popular writer Arthur Burks provided a booklength discussion. ${ }^{27}$ Rolf herself presented her views in a number of journal articles, some of which featured beforeand-after photographs. ${ }^{28-31}$ Her only book-length presentation includes a remarkable wealth of photographs and anatomical illustrations. ${ }^{2}$ Rosemary Feitis, who was Rolf's personal secretary for many years, has edited a compilation

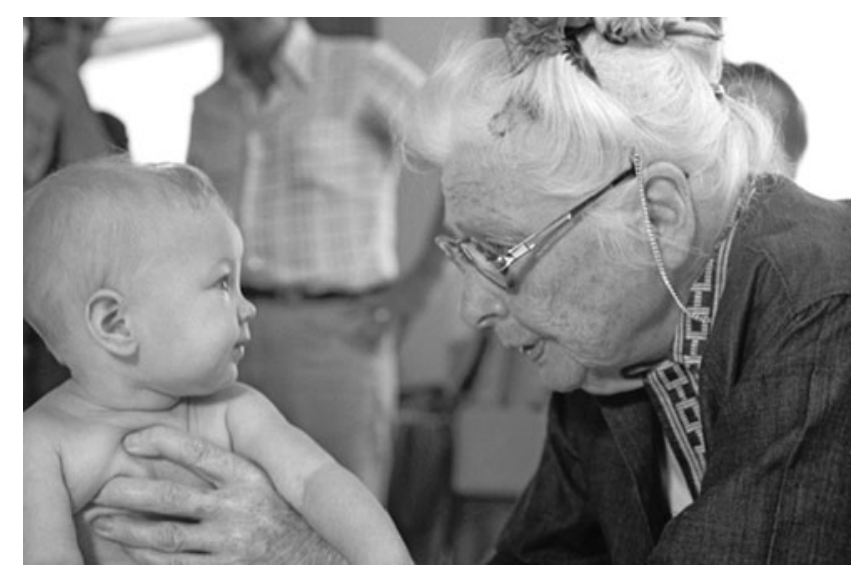

FIG. 3. Dr. Rolf treating an infant. (C) Copyright Ron Thompson. Used by permission. 
of excerpts from her classroom lectures ${ }^{7}$ and an anthology of memorabilia. ${ }^{8}$

In keeping with her long-standing involvement in movement therapies, Rolf also collaborated with the educator Dorothy Nolte and the dance teacher Judith Aston during the 1960s and 1970s to develop a method of movement awareness education that would reinforce the goals of her method. ${ }^{\S}$

\section{Movement Toward Professionalization}

In 1971, Rolf's teaching activities were consolidated under the Rolf Institute of Structural Integration (RISI) ${ }^{\|}$(Fig. 3). As of 2010, the RISI had graduated 1536 practitioners, including significant numbers trained in Germany, Brazil, Japan, and Australia. In 1990, a group of senior RISI faculty split off to form the Guild for Structural Integration," which had 628 graduates as of 2010. Since then, the numbers of practitioners and training institutes have multiplied at an accelerating rate, at first within the United States and then internationally. In 2004, Myers listed 14 different training institutes in the United States alone. ${ }^{10}$ In 2002 an umbrella organization, the International Association for Structural Integrators (IASI) $^{\#}$ was formed to develop standards for training, certify practitioners, and coordinate lobbying efforts toward licensure. IASI began examination-based certification in 2007. As of April 2010, it included 18 training organizations, and approximately 700 practitioners in 14 countries. The Ida P. Rolf Research Foundation was formed in 2007 to promote the scientific investigation of SI.** As of 2011, the Foundation had supported a research project on back stiffness and two conference travel grants, and had also played a major role in producing a series of international conferences devoted to fascia research. ${ }^{32-34}$ In addition to the proliferation of practitioners and training institutes that are devoted specifically to SI, Rolf's concepts and methods have influenced a wide range of other contemporary manual therapies. A growing number of organizations of local, national, and international scope offer training in "structural massage" or in techniques of fascial manipulation that are clearly derivative, but focus on the treatment of specific symptoms. Such techniques are increasingly employed by massage therapists, chiropractors, and physical therapists. Taking into account both the graduates of SI institutes and other types of manual therapists trained in derivative techniques, Myers estimated a total of $3000-4000$ practitioners employing some variant of SI as of $2004 .^{10}$

\footnotetext{
${ }^{\S}$ Prior to collaborating with Aston, Nolte taught her method under the name of Structural Awareness. In 1977 Aston broke away from the Rolf Institute and formed her own school that promotes an integration of sensorimotor education with manipulation. Aston Kinetics, P.O. Box 3568, Incline Village, NV 89450 www.astonkinetics.com accessed April 1, 2011

"Rolf Institute of Structural Integration, 5055 Chaparral Ct., Suite 103, Boulder, CO 80301; www.rolf.org Accessed April 1, 2011.

Guild for Structural Integration, P.O. Box 1559, Boulder, CO 80302; www.rolfguild.org Accessed April 1, 2011.

"International Association for Structural Integrators, P.O. Box 8664, Missoula, MT 59807; www.theiasi.org Accessed April 1, 2011.

**Ida P. Rolf Research Foundation; www.rolfresearchfoundation. org Accessed April 1, 2011.
}

Although Rolf intended SI to be a method by which healthy individuals could approximate structural ideals that were distinctly beyond the norm, it has been of increasing resort for the treatment for musculoskeletal pain and dysfunction, a trend that has been promoted by reimbursement for SI when billed as a type of massage therapy by Workmen's Compensation boards and insurance companies in several states.

Rolf's students have produced a lively secondary literature of theory, ${ }^{35-38}$ clinical technique, ${ }^{39,40}$ and accounts of client experiences. ${ }^{41-44}$ A number of publications have summarized these aspects of SI for medical readers, ${ }^{45-53}$ and others for the general public. ${ }^{54-58}$ Myers has provided historical and theoretical overviews and an account of the major variants of SI as of 2004. ${ }^{10,59,60}$ Rolf's incorporation of sensorimotor awareness education as an integral component of her method has also been carried forward. The work of the French movement teacher Hubert Godard has influenced many SI practitioners and instructors, as well as practitioners of Rolf Movement. ${ }^{\circledR}$ In addition, some SI practitioners have propagated their own systems of sensorimotor education as congruent with Rolf's ideas. ${ }^{61-64}$

\section{Acknowledgments}

Substantial insight and points of history were provided by Rosemary Feitis and Jeffery Burch, both members of the Rolf Institute of Structural Integration, and by Richard Demmerle, a son of Dr. Rolf. Guidance in the preparation of the manuscript was provided by Ted Kaptchuk of Beth Israel Deaconess Medical Center, Harvard Medical School. Research and manuscript preparation was supported by grants K01AT004916 and K24AT004095 from the National Center for Complementary and Alternative Medicine, National Institutes of Health (NCCAM/NIH).

\section{Disclosure Statement}

The author is a practitioner of Structural Integration, a professional member and chairperson of the research committee of the Rolf Institute of Structural Integration, and a member of the scientific review committee of the Ida P. Rolf Research Foundation. He was an unpaid co-investigator on an NCCAM/NIH grant supporting the First International Congress on Fascia Research (R13AT004146).

\section{References}

1. Jacobson E. Structural Integration: an alternative method of manual therapy and sensorimotor education. J Comp Altern Med 2011;in press.

2. Rolf I. Rolfing: The Integration of Human Structures. Santa Monica, CA: Dennis-Brown, 1977.

3. Anon. An interview with Ida Rolf. Somatics, Spring 1979;9-12.

4. Connolly L. Ida Rolf. Hum Behav, May 1977:17-23.

5. Demmerle R. Memories of an exceptional pioneer. Structural Integr 2007;35:7-8.

6. Demmerle A. A brief talk about Ida Rolf. Structural Integr 2007;35:5-6.

7. Feitis R. Ida Rolf Talks About Rolfing and Physical Reality. New York: Harper and Row, 1978.

8. Feitis R, Schultz L. Remembering Ida Rolf. Berkeley, CA: North Atlantic Books, 1996. 
9. Johnson S. Ida Rolf and the Two Paradigms. The Guild Online (Newsletter of the Guild for Structural Integration) 2006;1:26-40.

10. Myers T. Structural Integration: Developments in Ida Rolf's 'recipe'. I. J Bodywork Movement Ther 2004;8:131-142.

11. Sutherland W. The Cranial Bowl. Mankato: Free Press, 1939.

12. Thomas I, Thomas JR, Rosenthal R, et al. Physio-synthesis: Inner Muscle Balancing. Springfield, IL: Charles C. Thomas, 1998.

13. Still AT. The Fascia. In: Still AT, ed. Philosophy of Osteopathy. Kirksville, MO: 1899:22-23.

14. Mensendieck B. Look Better, Feel Better. New York: Harper and Row, 1954.

15. Todd M. The Thinking Body. Brooklyn, NY: Dance Horizons, 1968.

16. Sweigard L. Human Movement Potential: Its Ideokinetic Facilitation. New York: Harper and Row, 1974.

17. Lawson-Woods D. Psycho-Logics and Posture. Ashington, England: Daniel, 1958.

18. Lee J. This Magic Body. New York: Viking, 1946.

19. Brooks C. Sensory Awareness. New York: Viking, 1974.

20. Feldenkrais M. Body and Mature Behavior: A Study of Anxiety, Sex, Gravitation, and Learning. New York: International Universities Press, 1949.

21. Melton J. Pierre Arnold Bernard. In: Melton JG, Clark AA, Kelly AA, eds. New Age Encyclopedia. Detroit: Gale Research, 1990:64-65.

22. Love R. The Great Oom: The Improbable Birth of Yoga in America. New York: Penguin USA, 2010.

23. Korzybski A. Science and Sanity. Brooklyn, NY: Institute of General Semantics, 1994.

24. Pugh A. An Introduction to Tensegrity. Berkeley, CA: University of California, 1976.

25. Reich W. Character Analysis. New York: Simon and Schuster, 1978.

26. Solit M. A study in structural dynamics. J Am Osteo Assoc 1962;62:30-40.

27. Burks A. Human Structural Dynamics. Lakemont, GA: CSA Publishers, 1964.

28. Rolf I. Structural Integration: Gravity, an unexplored factor in a more human use of human beings. Systematics 1963;6:67-84.

29. Rolf I. Structural Integration: A contribution to the understanding of stress. Confinia Psychiatr 1973;16:69-79.

30. Rolf IP. The vertical-experiential side of human potential. J Humanistic Psych 1978;18:37-39.

31. Rolf I. Structure: A new factor in understanding the human condition. Somatics Mag 1979;Spring:6-8.

32. Findley T, Schleip R. Fascia Research: Basic Science and Implication for Conventional and Complementary Health Care. Amsterdam: Elsevier, 2007.

33. Findley T. Fascia Research II: Second International Fascia Research Congress. Int J Therapeut Massage Bodywork 2009;2:4-9.

34. Grimm D. Cell biology meets Rolfing. Science 2007;318:1234.

35. Maitland J. A phenomenology of fascia. Somatics 1980;Autumn:15-21.

36. Maitland J. Spacious body: Explorations in somatic ontology. Berkeley, CA: North Atlantic Books, 1995.

37. Myers T. Anatomy Trains: Myofascial Meridians for Manual and Movement Therapists. Edinburgh: Churchill Livingston, 2001.

38. Schultz R, Feitis R. The Endless Web: Fascial Anatomy and Physical Reality. Berkeley, CA: North Atlantic Books, 1996.
39. Maitland J. Cultivating the vertical: The Rolf method of Structural Integration. In: Coughlin MMP, ed. Principles and Practice of Manual Therapeutics. New York: Churchill Livingston, 2002:89-99.

40. Maitland J. Spinal Manipulation Made Simple: A Manual of Soft Tissue Techniques. Berkeley, CA: North Atlantic Books, 2002.

41. Schutz W, Turner E. Evy: An Odyssey into Bodymind. New York: Harper \& Row, 1976.

42. Salveson M. Rolfing. In: Johnson DH, ed. Groundworks: Narratives of Embodiment. Berkeley, CA: North Atlantic Books, 1997:32-53.

43. Anson B. Rolfing: Stories of Personal Empowerment. Berkeley, CA: North Atlantic Books, 1998.

44. Jacobson E. "Getting Rolfed": Structural bodywork, biomechanics and embodiment. In: Oths KS, Servando ZH, eds. Healing by Hand: Bonesetting and Manual Medicine in Global Perspective. Walnut Creek, CA: Altamira Press, 2004:171-193.

45. Hammann K. What Structural integration (Rolfing) is and why it works. The Osteopathic Physician, March 1972.

46. Bernau-Eigen M. Rolfing: A somatic approach to the integration of human structures. Nurse Pract 1998;9: 235-242.

47. Deutsch J, Judd P, DeMassi I. Structural Integration (Rolfing). In: J Carlson, ed. Complementary Therapies and Wellness. Upper Saddle River, NJ: Prentice-Hall, 2003:256267.

48. Deutsch J. The Ida Rolf method of Structural Integration. In: Davis C, ed. Complementary Therapies in Rehabilitation: Evidence of Efficacy. Thorofare, NJ: Slack, 2004:99-105.

49. Fromet Y. Therapeutic renewal: Rolfing or Structural Integration. Krankenpfi Soins Infirm 1984;77:68-69.

50. Boyce J. Understanding Rolfing. Phys Ther Forum 1988;7: $1-3$.

51. Jones T. Rolfing. Phys Med Rehab Clin N Am 2004;15:799_ 809.

52. Newton A, Bret N, Stolzoff R. Rolfing ${ }^{r}$ Structural Integration. In: DW Novey, ed. Clinician's Complete Reference to Complementary/Alternative Medicine. St. Louis: Mosby/ Harcourt, 2000:444-452.

53. Tavrazich J. Rolfing, Hellerwork and Soma. In: Davis C, ed. Complementary Therapies in Rehabilitation. Thorofare, NJ: Slack, 1997:69-80.

54. Johnson D. The Protean Body: A Rolfer's View of Human Flexibility. New York: Harper and Row, 1977.

55. Brecklinghaus H. Rolfing: Structural Integration. La Vergne, TN: Lightning Source, 2002.

56. Fahey B. The Power of Balance: A Rolfing View of Health. Portland, OR: Metamorphosis Publishers, 1989.

57. Mixter J. Rolfing. In: Lowe C, Nechas G; Prevention Magazine Editors, eds. Whole Body Healing. Emmaus, PA: Rodale Press, 1983:351-363.

58. Reid G. The Complete Book of Rolfing. New York: Drake, 1978.

59. Myers T. Structural Integration: Developments in Ida Rolf's 'recipe'-Part 2. J Bodywork Movement Ther 2004;8:189198.

60. Myers T. Structural Integration: Developments in Ida Rolf's 'recipe'-Part 3. An alternative form. J Bodywork Movement Ther 2004;8:249-264.

61. Bond M. Rolfing Movement Integration: A Self-Help Approach to Balancing the Body. Rochester, VT: Healing Arts Press, 1993. 
62. Bond M. Balancing Your Body: A Self-Help Approach to Rolfing Movement. Rochester, VT: Healing Arts Press, 1996.

63. Bond M. The New Rules of Posture: How to Sit, Stand and Move in the Modern World. Rochester, VT: Healing Arts Press, 2007.

64. McHose C, Frank K. How Life Moves: Explorations in Meaning and Body Awareness. Berkeley, CA: North Atlantic Books, 2006.
Address correspondence to: Eric Jacobson, PhD

Department of Global Health and Social Medicine Harvard Medical School 641 Huntington Avenue Boston, MA 02115

E-mail: eric_jacobson@hms.harvard.edu 